\title{
Map Literacy Skill in Social Sciences Curriculum of Turkey: The Gap between Theory and Practice
}

\author{
Leyla DÖNMEZ1 \\ Eskişehir Osmangazi University, Eskişehir, TURKEY
}

1Res. Assistant,. Eskişehir Osmangazi University, Faculty of Education, Department of Social Sciences Education, Meşelik Kampüsü, 26040, Eskișeihr, Turkey. leyla.donmez [at] ogu.edu.tr. ORCID: 0000-0002-5785-2058

\begin{abstract}
The aim of this study was to analyze the attainments of map literacy skills in the 2018 Social Studies course curriculum according to the learning areas and examine the applicability of the program. The research sought answers to the following questions: 1 . How is the distribution of attainments related to map literacy skills in the 2018 Social Studies course curriculum by class levels and learning areas? 2 . What is the level attainments associated with map literacy in the 2018 Social Studies course curriculum related to the lower dimensions of map skills in the high school geography curriculum? 3. What is the applicability level of map literacy skills in the 2018 Social Studies course curriculum for student-centered learning activities? Looking at the results of the study, it was found that at fourth-grade level, there was an improvement in the global connections learning area, where four skills were included with map writing inPeople and Places and Environments. At fifth-grade level, it was found there were two attainments linked to map literacy in People Places and Environments, while there was one attainment in Global Connections. According to the results of the research, it was found that at sixth-grade level, there were four achievements in People, Places and Environments, one achievement in Production, Distribution and Consumption, and three achievements related to map literacy skills in Global Connections. Finally, at the seventh-grade level, it was found there were two achievements related to map literacy skills in the field of learning People Places and Environments. When Social Studies textbooks were examined, it was observed that map literacy skills and application activities were at a limited level. In Social Studies course learning areas, the level of applicability in terms of map literacy skills is quite high. The recommendations to be developed on this issue are to teach both teachers and students about Geographic Information Systems, where students can find application areas, support map literacy skills.
\end{abstract}

\section{Keywords}

Map Literacy Skill, Social Sciences Curriculum; High School Geography Curriculum, Turkey 
From the moment, humanity comes to earth, they strive to perceive and make sense of themself, their environment and the world. The way to hold on to the world and adapt is to get to know it enough. Education is of great importance in this identification process. Education is the process of making deliberate and desired changes in human behavior (Tay, 2005).

A map is the transfer of part or all of the earth to paper, using a scale. "In broader terms, the map is an example of a bird's-eye view of the Earth or part of it, reduced to the desired scale by mathematical methods, drawn on a plane with special signs" (Özey, Ünlü and Üçışık, 2002). Maps show perceived changes and continuities, and location and settlement characteristics of the country, and to see the world as concrete (Karakuş and Oğuz, 2013).

Maps are important for students to understand space and correctly interpret landforms. "The general goals of teaching are to provide enough key information, not to fill students ' minds with very detailed information, but to teach them how to provide and use information when and where it is necessary, and to give students knowledge, skills to make value judgments" (Buğdaycı and Bildirici, 2009).

"Geographical skills and, accordingly, map skills of Primary School students take a very important place in the Social Studies course " (Sönmez, 2010). In order to get the most out of maps, map knowledge must be taught in primary Social Studies courses (Üzümcü, 2007).

One of the central coordinates of (school) Geography is represented by maprelated skills. Therefore, both cartography and teaching map skills are part of every program that trains future Geography teachers. Map skill acquisition, however, starts at a much earlier age to formal education in Geography. Regarding formal education, kindergarten and primary school introduce the basics of spatial orientation and map skills. Within this framework, teaching staff are required to facilitate a progressive acquisition of spatial awareness including the capability to represent space. In other words, kindergarten and primary school teachers should foster learners to perceive, understand, and construct mental representations of the physical space starting from the local scale of the home environment and ranging to the global scale. These representations facilitate both the best possible adaptation to the environment they live in and an efficient and balanced use of resources (Dulamă, 2011).

\section{Theoretical Framework}

Many tools and materials are used in Social Studies teaching, especially visual materials. It is known that visual materials are more effective than written materials and some students learn more easily through visual descriptions. Therefore, it is very important to be able to use visual elements. Visual materials used in Social Studies courses are important to include for students in order to help them understand the text they are reading and to develop a critical point of view (Çelikkaya, 2017).

To get accurate information from the map, you need to use the map correctly. This is also called map literacy (Alıml, 2007). Maps are the most essential tool of Geography. Because they help visualize the place (Geography for Life, 1994). 
Maps are one of the most widely used course materials in Social Studies (Taşkaya and Bal, 2010). However, it is important that the maps used are suitable for the student's class level and abilities (Buğdaycı and Bildirici, 2009).

Buğdaycı and Bildirici (2009) define a map as a "communication tool that show where, how, and how positional information is found". The purpose of using maps is to provide various information about the region in which it is a map (Koçyiğit and Yilmaz, 2009). The use of maps help to develop problem-solving skills related to location and location, allow critical thinking and access to information (Akengin, Tuncel and Cendek, 2016).

According to Castner (1990) students should learn Geography with the map (Taş, 2006). Using maps is a necessity for Geography in schools. Students must develop some basic knowledge about maps (Doğanay, 1993).

In the Social Studies course, a relationship can be established between the subjects in each class and the map used (Köstüklü, 2011). Besides map knowledge, it is important to develop map literacy skills. Today, it is of great importance to provide map literacy skills to train students with innovative thinking systems and to support this with understanding about Geographic Information Systems (GIS).

The research sought answers to the following questions:

1. How does the distribution of attainments related to map literacy skills in the 2018 Social Studies course curriculum occur by class levels and learning areas?

2. What are the level attainments associated with map literacy in the 2018 Social Studies course curriculum related to the lower dimensions of map skills in the high school geography curriculum?

3. What is the applicability level of map literacy skills related to the 2018 Social Studies course curriculum in terms of student-centered activities?

\section{Methodology}

This research was conducted by document review, which is one of the qualitative research patterns. During the research process, the 2018 Social Studies curriculum and textbooks from Grades Four, Five, Six and Seven were analyzed using document analysis technique.

\section{Research Design}

A qualitative method facilitates understanding and interpretation; it is often used in the Social Sciences and provides the researcher with an opportunity to have an in-depth understanding of the subject (Karataş, 2015). Furthermore, in the Social Sciences "multiple perspectives are needed to achieve holistic understanding of any phenomenon" (Yıldırım and Şimşek, 2016).

\section{Data Collection}

Document analysis, a qualitative research method is used to meticulously and systematically analyze the content of written documents (Wach, 2013). As with other methods used in qualitative research, document analysis requires the study 
and interpretation of data to make sense of it and create an understanding about the relevant topic, and to develop empirical knowledge (Corbin and Strauss, 2008). During the research process, the 2018 Social Studies course curriculum was analyzed according to the learning areas. The skill sought in learning areas was selected as map literacy skill. At the same time, the high school Geography curriculum has also been studied in the context of map skills. For this purpose, the 2018 Social Studies curriculum, the 2018 high school Geography curriculum and Social Studies textbooks were used.

\section{Findings}

The research was analyzed in accordance with sub-problems. In this study, the achievements of the 2018 Social Studies curriculum were analyzed according to map literacy skills, and the applicability of the program was examined.

Looking at the first sub-problem of the study, the following findings were reached. The distribution of attainments related to map literacy skills in the 2018 Social Studies curriculum by class levels and learning areas is given in Table 1.

Table 1

Distribution of Attainments Related to Map Literacy Skills in the 2018 Social Studies Curriculum by Class Levels and Learning Areas (MoNE, 2018b)

\begin{tabular}{|c|c|c|}
\hline Grade & Learning Area & Attainment \\
\hline 4 & $\begin{array}{l}\text { People, Place and } \\
\text { Environments }\end{array}$ & $\begin{array}{l}\text { SS.4.3.1. It makes inferences about the location of any place } \\
\text { around it. } \\
\text { SS.4.3.2. It sketches the places he uses in his daily life. } \\
\text { SS.4.3.3. It distinguishes the natural and human elements in } \\
\text { the environment in which it lives. } \\
\text { SS.4.3.5. It makes inferences about where it lives and the } \\
\text { landforms and population characteristics around him. }\end{array}$ \\
\hline 4 & $\begin{array}{l}\text { Global } \\
\text { Connections }\end{array}$ & SS.4.7.1. Introduces various countries around the world. \\
\hline 5 & $\begin{array}{l}\text { People, Place and } \\
\text { Environments }\end{array}$ & $\begin{array}{l}\text { SS.5.3.1. Maps explain the landforms of the place where it } \\
\text { lives and its surroundings in general. } \\
\text { SS.5.3.3. It gives examples of the natural features and effects } \\
\text { of human features on population and settlement. }\end{array}$ \\
\hline 5 & $\begin{array}{l}\text { Global } \\
\text { Connections }\end{array}$ & $\begin{array}{l}\text { SS.5.7.1. Explores the role of place and environment in } \\
\text { economic relations between our country and other countries. }\end{array}$ \\
\hline 6 & $\begin{array}{l}\text { People, Place } \\
\text { and } \\
\text { Environments }\end{array}$ & $\begin{array}{l}\text { SB.6.3.1. Defines the geographical location of continents, } \\
\text { oceans and our country using concepts related to location. } \\
\text { SS.6.3.2. It examines the main physical geography features of } \\
\text { Turkey, landforms, climatic features and vegetation on } \\
\text { related maps. } \\
\text { SS.6.3.3. It shows the basic human geography characteristics } \\
\text { of Turkey on the related maps. }\end{array}$ \\
\hline
\end{tabular}


Dönmez, L. (2021). Map Literacy Skill in Social Sciences Curriculum in Turkey: The Gap Between.....

\begin{tabular}{|c|c|c|}
\hline & & $\begin{array}{l}\text { SS.6.3.4. Based on human life in different natural } \\
\text { environments of the world, it makes inferences about climate } \\
\text { characteristics. }\end{array}$ \\
\hline 6 & $\begin{array}{l}\text { Production, } \\
\text { Distribution and } \\
\text { Consumption }\end{array}$ & $\begin{array}{l}\text { SS.6.5.3. It prepares investment and marketing project } \\
\text { proposals taking into account the geographical features of } \\
\text { Turkey. }\end{array}$ \\
\hline 6 & $\begin{array}{l}\text { Global } \\
\text { Connections }\end{array}$ & $\begin{array}{l}\text { SS.6.7.1. Analyzes the cultural, social, political and economic } \\
\text { relations of our country with the Turkish Republics and } \\
\text { neighboring states. } \\
\text { SS.6.7.2. Analyzes the economic relations of our country with } \\
\text { other countries. } \\
\text { SS.6.7.3. Analyzes the roles that our country assumes in the } \\
\text { international arena depending on its political, military, } \\
\text { economic and cultural characteristics. }\end{array}$ \\
\hline 7 & $\begin{array}{l}\text { People, Place } \\
\text { and } \\
\text { Environments }\end{array}$ & $\begin{array}{l}\text { SS.7.3.1. It makes inferences about factors affecting } \\
\text { settlement from the past to the present through sample } \\
\text { investigations. } \\
\text { SS.7.3.2. Interpret the demographic characteristics of Turkey } \\
\text { based on the factors affecting the distribution of the } \\
\text { population in Turkey. }\end{array}$ \\
\hline
\end{tabular}

Looking at the Table 1, it was found that there were four achievements associated with map literacy in People, Places and Environments at the fourth-grade level. Looking at the Global Connections learning area at the fourth-grade level, an acquisition was found to be associated with map literacy. At the fifth-grade level, two attainments were found to be involved in People, Places and Environments learning, while one attainment in Global Connections was found to be associated with map literacy skills.

In Table 1, four attainments were found to be related to map literacy skills when looking at People, Places and Environments at the sixth-grade level, while one attainment in Production, Distribution and Consumption and three attainments in Global Connections were related to map literacy skills. Looking at the seventh-grade level learning areas in the table, it was concluded that only the two attainments in People, Places and Environments are related to map literacy skills.

Looking at the second sub-problem of the study, the following findings were reached. The relationship of map literacy-related attainments in the 2018 Social Studies curriculum with the lower dimensions of map skills in the high school geography curriculum is given in Table 2 .

Table 2

The Relationship of Map Literacy Attainments in the 2018 Social Studies Curriculum with the Lower Dimensions of Map Skills in the 2018 High School Geography Curriculum (MoNE, 2018a) 


\begin{tabular}{|c|c|c|}
\hline Grade & $\begin{array}{l}\text { Learning } \\
\text { Area }\end{array}$ & Attainment \\
\hline 9 & $\begin{array}{l}\text { Natural } \\
\text { Systems }\end{array}$ & $\begin{array}{l}\text { 9.1.5. It makes inferences about the properties of time and place using } \\
\text { the coordinate system. } \\
\text { 9.1.6. It uses the map using the elements that make up the map. } \\
\text { 9.1.7. Explain the methods and techniques used to transfer } \\
\text { information to maps. } \\
\text { 9.1.12. It makes inferences about the characteristics and distribution } \\
\text { of different climate types on earth. } \\
\text { 9.1.13. It makes inferences about the characteristics of climate types } \\
\text { seen in Turkey. }\end{array}$ \\
\hline 9 & $\begin{array}{l}\text { Human } \\
\text { Systems }\end{array}$ & $\begin{array}{l}\text { 9.2.3. Explain the factors affecting the distribution of settlements in } \\
\text { Turkey with examples. } \\
\text { 9.2.4. Distinguishes settlements in Turkey according to their } \\
\text { administrative functions. }\end{array}$ \\
\hline 9 & $\begin{array}{l}\text { Global } \\
\text { Environm } \\
\text { ent: } \\
\text { Regions } \\
\text { and } \\
\text { Countries }\end{array}$ & $\begin{array}{l}\text { 9.3.1. Evaluates different regional samples in the world in terms of } \\
\text { their characteristics and the criteria used in determining the region. } \\
\text { 9.3.2. Explains the variability of region boundaries according to } \\
\text { purpose with examples. } \\
\text { 9.3.3. It classifies countries located in regions determined by various } \\
\text { geographical criteria using a map. }\end{array}$ \\
\hline 10 & $\begin{array}{l}\text { Natural } \\
\text { Systems }\end{array}$ & $\begin{array}{l}\text { 10.1.8. Evaluates the main landforms in Turkey in terms of their basic } \\
\text { properties and distribution. } \\
\text { 10.1.10. Explain the general characteristics and distribution of water } \\
\text { assets in Turkey. } \\
\text { 10.1.13. Correlates soil types with factors affecting the distribution of } \\
\text { soils in Turkey. } \\
\text { 10.1.16. Correlates climate and landforms with the distribution of } \\
\text { plant communities. } \\
\text { 10.1.17. Analyzes the distribution of natural plant communities in } \\
\text { Turkey in terms of growing conditions. }\end{array}$ \\
\hline 10 & $\begin{array}{l}\text { Human } \\
\text { Systems }\end{array}$ & $\begin{array}{l}\text { 10.2.3. Correlates the distribution of the world population with the } \\
\text { factors that affect the distribution of the population. } \\
\text { 10.2.6. Assesses the distribution of the population in Turkey in terms } \\
\text { of factors that are effective in the distribution of the population. } \\
\text { 10.2.8. It draws conclusions about the causes and consequences of } \\
\text { migrations around the world using historical texts, documents and } \\
\text { maps. }\end{array}$ \\
\hline 10 & $\begin{array}{l}\text { Global } \\
\text { Environm } \\
\text { ent: } \\
\text { Regions } \\
\text { and } \\
\text { Countries }\end{array}$ & $\begin{array}{l}\text { 10.3.1. Analyze international transportation lines in terms of their } \\
\text { regional and global impact. }\end{array}$ \\
\hline 10 & $\begin{array}{l}\text { Environm } \\
\text { ent and } \\
\text { society }\end{array}$ & $\begin{array}{l}\text { 10.4.1. Explain the causes and characteristics of disasters. } \\
\text { 10.4.2. Correlates the effects of disasters with their distribution. } \\
\text { 10.4.3. Correlates the effects of disasters in Turkey with their } \\
\text { distribution. }\end{array}$ \\
\hline 11 & $\begin{array}{l}\text { Natural } \\
\text { Systems }\end{array}$ & $\begin{array}{l}\text { 11.1.1. Explain the factors that are effective in the formation and } \\
\text { reduction of biodiversity. }\end{array}$ \\
\hline
\end{tabular}


Dönmez, L. (2021). Map Literacy Skill in Social Sciences Curriculum in Turkey: The Gap Between.....

\begin{tabular}{|c|c|c|}
\hline 11 & $\begin{array}{l}\text { Human } \\
\text { Systems }\end{array}$ & $\begin{array}{l}\text { 11.2.5. Interpret the global and regional effects of cities from a } \\
\text { functional point of view. } \\
\text { 11.2.6. Distinguishes cities in Turkey according to their functions. } \\
\text { 11.2.16. Explains the place of agriculture in Turkish economy. } \\
\text { 11.2.17. Explains the distribution of Turkey's mines and energy } \\
\text { resources. } \\
\text { 11.2.19. Explain the characteristics of the industrial sector in Turkey. }\end{array}$ \\
\hline 11 & $\begin{array}{l}\text { Global } \\
\text { Environm } \\
\text { ent: } \\
\text { Regions } \\
\text { and } \\
\text { Countries }\end{array}$ & $\begin{array}{l}\text { 11.3.1. Explain the factors that determine the emergence, spread and } \\
\text { distribution of the first cultural centers. } \\
\text { 11.3.2. Explain the factors affecting the spread of different cultural } \\
\text { regions on Earth. } \\
\text { 11.3.3. Analyze the spread areas of Turkish culture in terms of regional } \\
\text { characteristics. } \\
\text { 11.3.4. Assesses the fact that Turkey has been a center of civilizations } \\
\text { throughout history in terms of its location. } \\
\text { 11.3.5. It relates the trade between countries and regions and the } \\
\text { areas of raw materials, production and commerce. }\end{array}$ \\
\hline 12 & $\begin{array}{l}\text { Human } \\
\text { Systems }\end{array}$ & $\begin{array}{l}\text { 12.2.4. Analyze functional regions in our country according to their } \\
\text { characteristics. } \\
\text { 12.2.10. Analyzes world trade centers and networks in terms of their } \\
\text { place in the global economy. } \\
\text { 12.2.11. Explains the effects of trade centers in Turkey on tradable } \\
\text { products and flow directions. } \\
\text { 12.2.12. Evaluates historical trade routes in terms of Turkey's } \\
\text { position. } \\
\text { 12.2.13. Analyzes Turkey's foreign trade and its place in world } \\
\text { markets in terms of products subject to trade. }\end{array}$ \\
\hline 12 & $\begin{array}{l}\text { Global } \\
\text { Environm } \\
\text { ent: } \\
\text { Regions } \\
\text { and } \\
\text { Countries }\end{array}$ & $\begin{array}{l}\text { 12.3.1. Explains the change in the positional importance of continents } \\
\text { and oceans with examples. } \\
\text { 12.3.2. Assesses the regional and global implications of countries ' } \\
\text { position. } \\
\text { 12.3.4. Explains Turkey's relationship with the geopolitical regions in } \\
\text { which it is located. } \\
\text { 12.3.5. Explains the historical and cultural ties between Turkish } \\
\text { cultural regions and our country. } \\
\text { 12.3.9. Assesses the regional and global relations of countries in terms } \\
\text { of their natural resource potential. } \\
\text { 12.3.10. Explain the impact of major energy transmission lines in the } \\
\text { world on regions and countries. } \\
\text { 12.3.11. It links the spatial elements that create problems between } \\
\text { countries with today's conflict areas. }\end{array}$ \\
\hline 12 & $\begin{array}{l}\text { Environm } \\
\text { ent and } \\
\text { society }\end{array}$ & 12.4.4. Explains threats to common natural and cultural heritage. \\
\hline
\end{tabular}

In Table 2, it was determined that attainments related to map literacy in the 2018 Social Studies curriculum can be related to Natural and Human Systems, Environment and Community, and People, Places and Environments.

In addition, in 2018 the high school Geography curriculum for Global Contexts, the regional and country locations are the map skills and in the 2018 Social Studies 
curriculum, map literacy skills are associated with Global Connections.

In the third sub-problem of the study, the following findings were determined when looking at the level of applicability of map literacy skills related to the 2018 Social Studies curriculum in terms of student-centered activities. While students are expected to acquire map literacy skills only through activities in textbooks, it has been concluded that documents containing application areas that students can perform do not correspond to the level of skill they want to acquire. It has been observed that the activities of map skills are not sufficient in the books. In addition, it has been determined that the achievements included in the 2018 Social Studies curriculum are intended to be given only through thematic maps. Among the findings that there is no application site for students.

\section{Result and Discussion}

The Social Studies course is where students can find and learn the skills and values they can learn while living at the highest level. Artvinli (2009) argues that in our country, writing student-centered processes and activities for skills and values is very new. Teacher training provided by the Ministry of Education (MoNE) is faced with this new situation and the constructivist approach is very insufficient because teachers are trained according to the classical approach. According to Artvinli and Kaya (2010) Geography textbooks are part of the development of skills in Geography education. When the goals of the Geography curriculum are analyzed, it is easy to understand that achieving these goals can only occur through processes and activities aimed at developing skills.

Geographical skills and, accordingly, map skills of Primary School students take a very important place in the Social Studies course (Sönmez, 2010). In order to get the most out of maps, map knowledge must be taught in the primary Social Studies course. (Üzümcü, 2007). No course can be taught without the use of teaching tools and materials, and it is unthinkable that a Social Studies course should be taught without the use of appropriate teaching tools and materials. At the beginning of these teaching tools are maps (Güneș, 2016).

In order to see the purpose of Geography, it is necessary to move from the descriptive stage to the geographical inquiry stage, which is the researcher, the interrogator. The inquiry stage reveals a mutual adding to a causes, and requires on to use and disseminate extensively from the educational process. Along with providing students with the skills required by geographical inquiry, the importance and necessity of the function and enjoyment of Geography can also be understood (Artvinli, 2020).

First of all, geographical questioning skills should be developed in Geography courses to help students understand the environment in which they live because Geography examines the physical and human environments of the world and their interactions with each other and with humans. What makes Geography different from other disciplines is that it focuses on logical research and analysis in this way.

Geographers also investigate the connections between structures such as large landforms, migrations, economic features, and their causes. This research process is 
called geographic inquiry. It covers an individual and collaborative process and research that begins with questioning and progresses through the development of activities and the collection, evaluation, interpretation and analysis of results (Artvinli, 2020).

Map skills are required in the basic sense for almost all of the disciplines that make up the Social Studies course. From an early age, maps and spheres should be used so that children can understand the basis of Geography and recognize the environment in which they are located. School-age students can only do this with a Social Studies course (Sönmez, 2010). In a study by Göksel (2007), which examined the level of support for education in the use of maps and graphs in Social Studies teaching, it was revealed that the most important auxiliary material used by Social Studies teachers was maps (55\%). In the same study, it was found that the most important course material in the Social Studies course was a map (59\%).

Clever use of maps by teacher and student can make teaching and learning activities interesting and useful (Taşli, 2000). In most studies that examined the states of Social Studies teachers ' use of teaching tools, it was found that the map and Earth Sphere model are the most commonly used teaching tools (Aydemir, 2012; Taşkaya and Bal, 2010; Çoban and İleri, 2013; Çelikkaya, 2013).

Map literacy can provide the individual with the opportunity to understand and interpret thoughts, actions, objects, graphics and symbols, creating awareness of lifelong learning, attainment problem-solving skills with effective learning in developing this consciousness. In order to understand the formats in which information is produced and used in the information age, today's person must be multi-literate (Duman and Girgin, 2007).

The Turkish Geography curriculum emphasizes geographical enquiry and progress rather than delivering some concrete body of geographical knowledge. Then it gives a great deal of importance to the fact that various learning methods should involve students actively through an activity-based and constructivist education. These are possible only by developing skills that will enable students to observe patterns, associations, and spatial order (Artvinli, 2012).

Children from an early age should use maps and spheres to understand geography and recognize the environment in which the student is located. At school age, they can achieve this only when they are raised as map literate with a social studies course (Sönmez, 2013).

Tuna and Balcl (2013) using the map in the application of geographical skills are used in orienteering, participants (to be able to read symbols and scales, distance, surface features to be able to read) on the map, and navigation in the field, determine the location using the Compass, field studies, preparation of practice with geographical information data acquisition, real-life skills to cope with problems and has determined that as many conflicting situations can improve.

\section{Suggestions}

It is also important to prepare an application field for students who can perform activities to improve their map skills. Smart boards are made with innovative 
technology to support learning of the class and the workshop where the conditions of increased education and training, Geographic Information Systems, and expanded reality, such as the first teachers of training and then be given to the students to develop their skills is very important for map. Only the information left in theory will thus find an application site.

Today, the power of technology is undeniably important. Along with these trainings, textbooks should also be organized in accordance with the innovative learning model. Map skills can be acquired from early childhood. With the support of the technological infrastructure, it should be the main reason for map literacy skills to train teachers who can use these skills first and then students who have these skills.

\section{References}

Artvinli, E. (2009). The level of the access to geographic skills in the 9. year geography textbook according to geography curriculum. Erzincan University Journal of Education Faculty, 11(2), 51-66. Retrieved from https://dergipark.org.tr/en/pub/erziefd/issue /6001/80019.

Artvinli, E. \& Kaya, N. (2010). Implementation level of geographic skills in 11. year geography textbook. Turkish Journal of Social Research, 14(1), 305-320. Retrieved from https://app.trdizin.gov.tr/publication/paper/detail/TVRBNE5UY3dNQT09.

Artvinli, E. (2012). Integrate geographic skills with active learning in geography: a case of Turkey, Journal of Research and Didactics in Geography (J-READING), 0, 1, 43-50, DOI: 10.4458/1005-06. Italy. Retrieved from http://j-reading.org/index.php/geography /article/viewFile/6/6.

Artvinli, E. (2020). Coğrafi sorgulama becerisi. In Ç.Ö. Demirbaş (Ed.), Coğrafi beceriler (1st ed.). Ankara: Nobel Yayın Dağıtım.

Akengin H., Tuncel, G., ve Cendek, M. E. (2016). The Social Sciences Teachers' Opinions About Developing Map Literacy of Students. Marmara Geographical Review, S. 34, p. 61-69. Retrieved from https://avesis.marmara.edu.tr/yayin/a18c357a-ac27-4cf9aab1-3bc9d0eb7c42/the-social-sciences-teachers-opinions-about-developing-mapliteracy-of-students.

Alımlı, M. E. (2007). Map Use and Map Awareness. Thesis (M.Sc.), İstanbul Technical University, Institute of Science and Technology, İstanbul.

Aydemir, H. (2012). Levels of Using Educational Instruments by Social Sciences Teachers. Cumhuriyet University Journal of Social Science, 36, 1. Retrieved from https://dergipark.org.tr/tr/download/article-file/49871.

Bilgili A. S. (ed.), (2013). Sosyal Bilgilerin Temelleri, 6. bs. Ankara.

Buğdaycı, İ. ve Bildirici, İ. O. (2009, May). Harita Kullanımının Coğrafya Eğitimindeki Önemi. TMMOB Harita ve Kadastro Mühendisleri Odası 12. Türkiye Harita Bilimsel ve Teknik Kurultayl, Ankara. Retrieved from https://www.hkmo.org.tr/resimler/ekler /f489f642a0ddb10_ek.pdf.

Castner, H.W. (1990): Seeking New Horizons: A Perceptual Approach to Geographic Education. Montreal: McGill-Queen's University Pres.

Corbin, J. \& Strauss, A. (2008). Basics of qualitative research: Techniques and procedures for developing grounded theory. Thousand Oaks: Sage. 
Çelikkaya, T. (2013). The application levels of instructional tools and materials by social studies teachers. On dokuz Mays University Journal of Faculty of Education, 32, (1), 73105. Retrieved from https://www.researchgate.net/publication/307806877_ THE_CONDITION_USING_OF_INSTRUCTIONAL_TOOLS_AND_MATERIALS_BY_SOCIA L_STUDIES_TEACHERS.

Çoban, A ve İleri, T. (2013). The Level of Social Studies Teachers' Using Teaching Techniques and Materials and the Reasons of Their Inability to Use Them. Amasya University Journal of Faculty of Education, 2(1), 194-213. Retrieved from https://www.acarindex.com/amasya-universitesi-egitim-fakultesi-dergisi/sosyalbilgiler-ogretmenlerinin-ogretim-teknolojileri-ve-materyalleri-kullanma-duzeylerive-kullanamama-sebepleri-59454.

Doğanay, H. (1993). Coğrafya'da Metodoloji: Genel Metodlar ve Özel Öğretim Metodları, Milli Eğitim Bakanlığı, Öğretmen Kitapları Dizisi, İstanbul.

Dulamă, M.E. (2011). Geografie şi didactica geografiei pentru învăţământul primar şi preşcolar. Cluj-Napoca: Presa Universitară Clujeană.

Duman, B.; Girgin, M. (2007). Faculty of Education Students' Views on Map Literacy. Eastern Geographical Review, 12 (17), 185-202. Retrieved from https://dergipark.org.tr/en/ download/article-file/26876.

Geography for Life. (1994). The National Geography Standarts 1994. Washington D.C.: Geography Education Standarts Project.

Göksel, 0. (2007). The usage of the maps and the graphs at social studies education supporting level. Thesis (M.Sc.). Celal Bayar University, Manisa.

Güneș, G. (2016). Social Studies Preservice Teachers' Mapping Skills. Thesis (M.Sc.). Ahi Evran University, Kırşehir.

Karakuș, U. \& Oğuz, S. (2013). Using Google earth in geography topics in social studies lesson and teachers' opinions. International Journal of Eurasia Social Sciences, 4, 110-125. Retrieved from http://www.ijoess.com/Makaleler/1402185016_110125\%20sibel $\% 200 \%$ c4\% 9 fuz.pdf.

Karataş, Z. (2015). Qualitative research methods in Social Sciences. Manevi Temelli Sosyal Hizmet Araştırmaları Dergisi, 1(1), 62-80. Retrieved from https://avys.omu.edu.tr.

Koçyiğit, E. ve Yılmaz, İ. (2009). Writing on the Map and Basic Properties. Harita Teknolojileri Elektronik Dergisi, C. 1, No: 2, 1-9. Retrieved From https://dergipark.org.tr/tr/pub/hartek/issue/7603/99680.

Köstüklü, N. (ed.) (2011). İlkoğretim Sosyal Bilgiler 6 Öğretmen Kılavuz Kitabı, Ankara.

Ministry of National Education-MoNE (2018a). Ortaöğretim Coğrafya dersi (9, 10, 11 ve 12. sınıflar) öğretim programı, Ankara: Devlet Kitapları Müdürlüğü.

Ministry of National Education-MoNE (2018b). Sosyal bilgiler dersi öğretim programı (ilkokul ve ortaokul 4, 5, 6 ve 7. sinıflar), Ankara: Devlet Kitapları Müdürlüğü.

Özey, R., Ünlü, M. \& Üçışık, S. (2002). Importance of the maps in geography education and instruction. Marmara Geographical Review, 5, 9-25. Retrieved From https://dergipark.org.tr/tr/pub/marucog/issue/452/567516.

Sönmez, Ö. F. (2010). Map skills in elementary social studies teaching. Thesis (PhD). Gazi University, Ankara. 
Taşkaya, M.T., Bal, T. (2010). The Cases of Primary School's Teachers in Using the Tools for Course Social Sciences. Akademik Bakış Dergisi, 22, 1-16. Retrieved From https://www.acarindex.com/dosyalar/makale/acarindex-1423868187.pdf.

Taşlı, İ. (2000). Sosyal bilgiler öğretimi. Manisa: Tekin Matbaası.

Tay, B. (2005). Learning strategies in social studies textbooks. Kırşehir Eğitim Fakültesi Dergisi, 6(1), 209-225. Retrieved From https://kefad.ahievran.edu.tr /InstitutionArchiveFiles/f44778c7-ad4a-e711-80ef-00224d68272d/d1a3a581af4a-e711-80ef 00224d68272d/Cilt6Sayi1/JKEF_6_1_2005_209_225.pdf.

Üzümcü, O. N. (2007). Obtaining map-reading skills by active learning method in Primary School sixth grade social studies course. Thesis (M.S.c). Gazi University. Ankara.

Wach, E. (2013). Learning about qualitative document analysis. IDS Practice Paper in Brief. 2013. Retrieved from https://www.ids.ac.uk/publications/learning-aboutqualitative-document-analysis/.

Yıldırım, A. \& Şimşek, H. (2016). Sosyal bilimlerde nitel araştırma yöntemleri. Ankara: Seçkin.

\section{Biographical Statement}

Leyla DÖNMEZ is a research assistant at the faculty of education in Eskişehir Osmangazi University, Eskişehir, Turkey. She is also a Ph.D. student in social studies education at the faculty of education in Anadolu University, Eskişehir, Turkey. Her interests are on social studies education, map skills and geographical education. 